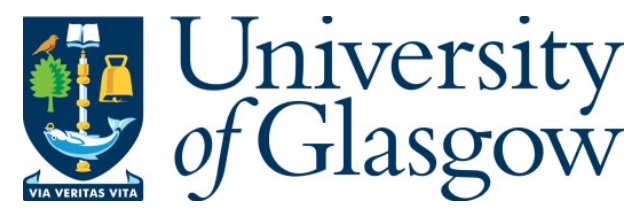

Chikhladze, T. and Aliyev, H. (2019) Towards an "uncivil" society? Informality and civil society in Georgia. Caucasus Survey, 7(3), pp. 197-213.

(doi: $10.1080 / 23761199.2019 .1690384)$

There may be differences between this version and the published version. You are advised to consult the publisher's version if you wish to cite from it.

http://eprints.gla.ac.uk/203295/

Deposited on: 15 November 2019

Enlighten - Research publications by members of the University of Glasgow http://eprints.gla.ac.uk 


\title{
Towards an "Uncivil" Society? Informality and Civil Society in Georgia
}

\author{
Tatia Chikhladze ${ }^{1}$ and Huseyn Aliyev ${ }^{2}$
}

\begin{abstract}
Since the early 1990s, the NGO sector in the South Caucasus has faced countless challenges on its road to development. Among these, an endemic "informalisation of society" - to a certain degree inherited from the Soviet Union - posed a seemingly insurmountable number of obstacles for the emergence and establishment of an egalitarian and open civil society in the region. This study explores the uneasy relationship between formal civil society and the informal sphere in the republic of Georgia. We argue that scholars and policy-makers alike need to pay close attention to how informal institutions, regardless of their non-civil nature, often become part of the civil sector in the context of developing countries. Informal patronage networks, radical movements and extremist organizations - some registered and some remaining informal - often pose as civil society organisations, functioning as a "dark" side of NGOisation in post-Communist countries. This "uncivil" society thrives due to the low popular participation in formal civil society in this region and undermines the potential gains to be made by the development of a robust civil sector.
\end{abstract}

Keywords: civil society, informal networks, NGOs, uncivil society, Georgia

\section{Introduction}

This article investigates the influence of informal institutions ${ }^{3}$ and "uncivil" society on formal civil association in the post-Soviet republic of Georgia. Our theoretical argument rests upon two interrelated assumptions. Firstly, we argue that in the context of the former Soviet Union informal institutions have a potential to negatively affect the formal civil society. Informal networks and other forms of bonding social capital (Hooghe and Stolle 2003; Rothstein and Stolle 2008) ${ }^{4}$ have served as coping mechanisms and private safety nets for the Georgian population for centuries (Curro 2017). In the absence of efficient and transparent formal institutions, including civil society, informal institutions have filled the institutional niche by performing functions traditionally reserved for civil society and the state. These functions include assisting in emergencies, or during moments of need, alleviating economic problems of the population and serving as venues for bonding and (occasional) bridging of social capital. Notwithstanding the positive effects of informal institutions, public goods are distributed through such institutions unequally, creating informal hierarchies and encouraging nepotism and favouritism. Following these observations, we argue that irrespective of the positive functions of informal institutions in the South Caucasus, the influence of informality on formal civil society in these countries 
can also be rather detrimental. That said, we believe that informal institutions have both positive and negative functions and it is beyond the scope of our study to compare or contrast these functions. Rather our goal is to focus on under-researched negative side of informal institutions.

Secondly, we argue that the impact of informal institutions on formal civil society ${ }^{5}$ often manifests itself in the emergence of the so-called "uncivil" society. The term "uncivil" society was first employed by Kopecký (2003) to describe radical organisations and movements in Central and Eastern Europe. For our study it assumes a different shape when applied to those forms of social capital which pose as civil society, but fail to perform in accordance with egalitarian and civic virtues engrained into the classical definition of civil society, as presented in the works of de Tocqueville (1967), Cohen and Arato (1992), Putnam et al. (1993). ${ }^{6}$ We define uncivil society as not limited to radical political and ideological extremist groups, such as those advocating the use of violence, or religious organisations marginalising individual rights and freedoms of selected minority groups (Kopecký 2003). In our study, the term "uncivil" society refers to a broad category of movements and groups, which may or may not be legally registered as CSOs, but, which openly claim to represent civic values.

Unlike traditional CSOs, promoting non-violence, tolerance, equality and humanitarianism (Keane 1998), "uncivil" groups prioritise a variety of goals, ranging from financial profit to ethnic self-identification, and deploy various non-civic means to achieve these ends. These groups are not necessarily illegal and many of these movements, such as ultra-radical Orthodox religious groups in Georgia, are registered as active civil society organisations. In contrast to NGOs, "uncivil" elements of civil society often emerge on the basis of informal institutions or grassroots movements. Many of these groups continue functioning as informal associations and never become formalised. Others assume formal roles and become part of formal civil society. Nonetheless, the former and the latter continue functioning as "uncivil" groups, advocating inequality, relying on violence and engaging in corrupt and uncivil practices. In addition, we describe as "uncivil" those NGOs, which exist for the sole purpose of grant-hunting and/or seeking material profits and, therefore, undermining one of the key principles of civil society as a non-profit sector.

In order to empirically support these arguments, this paper draws its insights from both close-ended representative surveys and open-ended interview data collected by the authors during fieldwork in Georgia in 2013. ${ }^{7}$ This paper seeks to draw attention to the crucial, yet often overlooked, impact of "uncivil" society groups on formal civil association.

\section{Informal Networks and Civil Society}


This section engages with literature on informal networking and informal institutions in the former Soviet Union and beyond, which allows us to place the empirical analysis of the Georgian case study in a broader theoretical and conceptual context. As earlier studies primarily focused on the negative aspects of informal economic activities in developing countries (Bromley and Gerry 1979), more recent research on informality began treating informal relations as need-based coping mechanisms employed by populations to counterbalance the inability of the state to provide basic services to the population (Castells and Portes 1987). Following the pioneering research on informal political institutions by O'Donnell (1994) and Helmke and Levitsky (2004), the initial focus on informal economy, dominant in most early studies on the informal sector, began incorporating informal political structures. As the research on micro-level aspects of informal relations in sociopolitical and socioeconomic spheres began spreading, scholars of informality increased their analytical focus on micro units of analysis such as networks.

Although the study of informal networks was well grounded in sociology (Granovetter 1973) and social anthropology (Boeke 1953), it was introduced into mainstream research on informality through studies by Lomnitz (1988), Mizstal (2002) and others (Mead 2009). Still shunned in institutional economics, networks, nonetheless, were deployed as primary units of analysis in research on informal political and social institutions by a voluminous body of literature (Putnam 2003; Helmke and Levitsky 2004). Despite a range of studies exploring the role of informal networks in civil association in developing countries (Castells and Portes 1987; Gerxhani 2004), the relationship between the informal sphere and civil society is still analysed through the prism of corruption and nepotism studies. Indeed, the intimate interaction between informal structures and corruption has been at the heart of attention for numerous research works on the organisational dynamics of NGOs in the developing world (Cooley and Ron 2002; Smith 2010; de Sousa et al. 2012).

Yet, due to a number of region-specific characteristics, the contentious relationship between formal civil society and the informal sphere acquires a slightly different shape in the context of the former Soviet Union. To start with, it has been well documented that unlike in other developing regions of the world, informality is both endemic and omnipresent in post-Communist countries (Smith 2002; Morris and Polese 2014). It has also been argued that the reliance on informal networks and institutions in the daily life of postSoviet societies is more important for the population than in other parts of the world (Round and Williams 2010). Research on the informal relations of former Soviet states began sprawling soon after the collapse of state Communism.

Among others, studies by Ledeneva (1998), Rose (1995) and Polese (2008), highlighted the essential nature of informality in post-Soviet societies. The key argument in research on post-Soviet informal institutions evolves around the assumption that informality became entrenched in Eastern European and Central Asian societies due to shortages in the Soviet 
command economy and the all-encompassing infiltration of the Communist state into the private and public spheres of the USSR (Ledeneva 1998). As the bulk of social and associational life was forced underground, informal networks thrived all across the Soviet Empire (ibid).

The notoriously widespread Soviet-Russian informal practice of blat, labelled by Ledeneva (1998) as the "economy of favours" and based on reciprocal exchanges of economic favours, was at the core of informal networking in both the Soviet and (for the most part of) the post-Communist periods. In Russia, as well as in other Soviet (and post-Soviet) republics, blat-practices existed upon an ensemble of informal relations sustained through networks. Empirically, blat has been compared and contrasted with similar practices around the world such as the Chinese quanxi, the Arab wasta and the Brazilian jeitinho (Amado and Brasil 1991; Cunningham and Sarayrah 1993; Yang 1994). One of the main conclusions of these studies was that informal practices differ among each other not in their functions, but in their spread and importance for the population (Smith 2002). It is with the regard to their scope and presence that post-Soviet informal institutions, including blat, surpass their counterparts from other regions of the world.

Since no systematic statistical data has ever been readily available to researchers of postSoviet informality, estimating the exact spread of informal relations among post-Soviet societies remains speculative. Nevertheless, as found in the European Bank of Reconstruction and Development (EBRD) surveys (2011), the daily reliance on informal payments and gifts among post-Communist citizens hardly matches the data from other developing countries (WVS 2014). More nuanced studies revealed that not only is informality widespread in post-Communist spaces, but the use of informal channels is also more common among post-Soviet citizens as compared to people from other (Central European and Yugoslav) former Communist states (Rose 1995; Smith 2002).

With the above in mind, the impact of the informal sphere on civil association in the former Soviet Union is also instrumental due to the particularly close synthesis between formal and informal associational life. Although informal structures, such as kinship groups, clans and communal associations have always been a part of traditional forms of civic association in many developing regions of the world (Lewis 2002), the interference of the Communist state into the private lives of its citizens under the Soviet rule has left a fairly unique imprint on formal-informal interaction in the post-Soviet region. The history of intermarriage between formal and informal civil associations, along with the history of informality in the region, dates back to the Soviet period and is closely associated with the emergence of informal dissident groups known as neformaly (informals) in the late Soviet period (196080s). Neformaly - represented by underground circles of intelligentsia, artistic clubs or simply groups of colleagues and friends sharing similar interests - were a surrogate form of civil association free from the all-pervading eyes of the Communist Party. 
In the post-Communist period, the appearance of the NGO sector was accompanied by a flourishing of informal forms of civil association represented by grassroots activism of all sorts, informal political campaigns and interest groups (Howard 2003). Across the Caucasus, informal civil association was traditionally engraved into the social structure of local communities which sought to merge indigenous social capital with formal civic association. For example, similar to some Central Asian republics (Collins 2006), indigenous civic association in Azerbaijan was traditionally confined to local communities, mahallas, which function as informal centres of social life (Habibov 2012; Sayfutdinova 2017). In Chechnya, Ingushetia and other traditionally clan-organized North Caucasian groups, indigenous civic association was centred on extended clans (tukhums) (Souleimanov and Aliyev 2014). In other non-clan centred societies in the North Caucasus, such as Dagestan and KabardinoBalkaria, as well as among the South Caucasus's Georgians and Armenians, traditional patriarchal extended families and kinship groups were primary centres of informal civic association.

The bulk of activities within these traditional informal forms of civic association engaged in community assistance, mutual help and in the development of reciprocal social safety nets. With the emergence of formal civil society, these informal civic structures often continued functioning alongside NGOs and, at times, were integrated into formal civil society (Babajanian 2008; Habibov 2012). This symbiotic relationship between formal and informal civil society is mutually reinforcing and is commonly perceived as positive. Previous studies have confirmed that the population's reliance on, for instance, kinship networks does not negatively affect the performance of formal civil society (Aliyev 2014). The positive side of formal-informal relations has previously been examined by the literature on social capital in the South Caucasus (Ishkanian 2008; Habibov 2012) which reveals that extensive human capital embodied in informal structures can both cooperate with and contribute to the work of civil society.

The emergence of an independent civil society - synonymous with the classical Western perception of the civil sector as a sphere distinctive from the state and the marketplace (Ehrenberg 1999; Cohen and Arato 1992) - in the former Soviet Union is associated with the fall of state Communism and the independence of the South Caucasus's republics from the USSR. Following the assumption that a robust NGO sector makes for greater democracy (Keane 1998), the development of civil society was heavily prioritised by democratisation actors in the region. Today, after almost three decades since the collapse of the Soviet Union, the civil societies of the South Caucasian states have received significant amounts of foreign aid and experienced extensive contacts with their counterparts from both international non-governmental organisations and international governmental organisations, such as the US government-run USAID (2009). 
Despite all of that, the civil societies of the post-Soviet countries still remain on the margins when it comes to counteracting the state and serving as checks and balances on political elites. The literature on civil society is rife with explanations as to why post-Soviet civil sectors are weak and dysfunctional. Persecution by authoritarian governments (Ambrosio 2010), the lack of a tradition of organised civic association (Nodia 2005), low public interest in civic association (Howard 2003), ineffective management of foreign aid (Green and Kohl 2007) and the persistent legacy of Communist institutions (Aliyev 2015b) are cited as the most prominent causes of the civil sector's weaknesses. Among these, low registered participation in the work of civil society is thus far the most obvious indicator of limited levels of the population's engagement with civil society. As reported by the 2014 Caucasus Barometer survey, conducted by the South Caucasus-based research centre CRRC, ${ }^{8}$ only two percent of the Georgian public mentioned membership in a CSO. This low membership in formal civil society is coupled with high levels of reliance on informal institutions. According to a survey by the EBRD, over 60 percent of the public in the South Caucasus rely regularly on informal safety nets and the use of informal channel (kinship and friendship) networks in emergency situations is among the highest in the former Soviet Union (CRRC 2013).

Notwithstanding the positive aspects of informal structures in the region, investigated in detail by a large and growing body of literature (Babajanian 2008; Aliyev 2014; Rekhviashvili 2016), the negative side of informal interactions and, in particular, its impact on formal civil associations remains relatively underexplored. It has been noted that due to extensive institutional reforms implemented over the past decade, administrative corruption significantly decreased in Georgia (Shelley et al. 2007; Rekhviashvili and Polese 2017). Yet the reliance on patronage networks and the importance of informal institutions for rentseeking and power distribution remain largely unperturbed in Georgia (Muskhelishvili and Jorjoliani 2009). Informal relations on the job market, in economic production and many other areas of the daily economic and social lives of the population are still very prominent (Aliyev 2014). As suggested by Howard (2003), one of the causes behind the weakness of post-communist civil society and the reason accounting for low popular participation in CSOs is the prevalence of friendship networks. Howard's hypothesis has been reiterated by other scholars who studied the civil societies of Russia (Rose 1995; Gibson 2001) and the Central Asian republics (Luong Jones 2002; Collins 2006), and even Central European EU states (Böröcz 2000; Grødeland and Aasland 2007).

Nonetheless, nuanced studies into the negative effects of informal institutions on formal civil society, not only in the South Caucasus, but also elsewhere, are notable by their absence. Besides, little is known as to how exactly informal institutions influence the performance of CSOs on the ground. Bearing in mind the importance of informal relations in Georgia and their all-pervading impact on formal institutions, this post-Soviet republic lends itself as an interesting laboratory for research on the relationship between civil society and informal institutions. 
Although this study is most of all an empirical examination of the relationship between formal civil society and informal institutions pertinent to area studies, it also pursues broader theoretical goals. In other words, this article seeks to demonstrate that in nonWestern contexts, civil association assumes a variety of forms, some of which may fall outside of the classical Western conceptualisation of civil society. Besides, civil society irrevocably becomes interrelated with other forms of social capital such as informal networks and similar informal institutions.

\section{What is "Uncivil" Society?}

Along with positive aspects of CSO development in the post-Soviet region, which has been thoroughly explored by a voluminous body of literature, there is also a "darker" side to the formal-informal relations. Previous studies have found that patronage and other forms of corrupt networks, common in post-Soviet societies, undoubtedly pervades the working of formal civil society (Aliyev 2015b). Many of these structures - for their own benefit - choose to remain informal and do not seek the status of civil society. Apart from these elements, there is also a growing number of informal structures which, for various reasons, seek formalisation and legalisation under the all-encompassing term of civil society. Bearing in mind that unlike those CSOs that are internationally recognised either as service-delivery or advocacy groups, these "shadowy" groups, generalised by Kopecký (2003: 10) as "antiliberal and antidemocratic," are referred to here under the collective term of "uncivil" society. In Azerbaijan:

Some of the more radical Islamist groups are often presenting themselves as NGOs. When they get persecuted [by the state] ... they claim that they do civil work. In reality, though they try to recruit more people and advance their ideas, some of which are against [secular] values. ${ }^{9}$

This type of uncivil group has been described by Collins (2007) in her study on religious organizations in Azerbaijan, as well as in more general terms portrayed by Swietochowski (2002). In Georgia, ultra-radical Orthodox groups have been similarly seeking to formalise their activities by either presenting their organisations as civil society groups or by assuming a broader status of popular grassroots movements. ${ }^{10}$

Bearing in mind that there is no ready-made to describe such "uncivil" CSOs in the context of the South Caucasus, we employ the term "uncivil" society and we insist that "uncivil" society extends well beyond anti-democratic or non-egalitarian movements and groups. Instead, the term "uncivil" society can be applied to a wide range of groups, which seek to act against and beyond the core principles of civil society: non-violence, equality, tolerance 
and all-inclusion. These principles are engendered in the distribution of public goods provided by civil society to all social groups within the population regardless of their political, religious or ethnic association. That said, the "uncivil" society differs from the region's widespread Government-Organised Non-Governmental Organisations (GONGOs) because, unlike GONGOs - many of which only differ from independent civil society due to their sources of funding and political affiliation - "uncivil" society makes little efforts to resemble NGOs either in their organisational structure, or operational methods.

Another important caveat in the distinctions between civil and "uncivil" groups is that the latter exist on the margin between formal and informal spheres. Some "uncivil" groups may actually be registered as NGOs, others may use the term without having legal registration, and yet many more may simply identify themselves as civil movements or popular associations. These murky characteristics of "uncivil" society are directly related to its informal roots. Indeed, typical for the South Caucasus's societies, methods of informal networking - embodied in the reliance on kinship, peer-groups and vertical patronage networks - lie at the core of "uncivil" groups. Informal relations tend to guide these groups' operational methods and recruitment patterns. ${ }^{11}$

It is crucial to distinguish the above detailed representatives of "uncivil" society from both radical (right- or left-wing) political parties and terrorist or criminal groups (Slade 2017), which also often become incorporated into the definition of "uncivil" society (Kopecký and Mudde 2003). The key definitive characteristic of "uncivil" groups - described in this article under the term "uncivil" society - is not only their radical stance vis-à-vis the state or liberal values, but their efforts to function as civil society. Having employed the rhetoric of civil society, and often received a legal status of CSOs, such groups are poised to take full advantage of being a part of civil society. Unlike political parties or movements and violent groups (such as skinhead gangs) or mafia, "uncivil" organisations struggle to legitimise and popularise themselves in the eyes of the public.

Apart from radical, extremist and other ideology-based elements composing "uncivil" society in the region, there are also numerous informal cliques, which seek to acquire the status of an NGO in order to gain access to grants and other sources of funding available to CSOs. As mentioned by an NGO official from Tbilisi: ${ }^{12}$

That is why [we] have a high number of registered NGOs. It means that if I call you tomorrow and say that there is a big opportunity to get some funding we go and create some NGO. There is even a saying that "is your NGO still registered?" because [if] there is a call [for grants] that maybe we can use your NGO for. 
As confirmed by informants from within the Georgian NGO sector, many of such granthunting CSOs disappear soon after they achieve (or fail) their goals of securing grant money. People at the core of these fake NGOs may use their networks and connections to once again form a similar organisation when an opportunity arises. These "uncivil" groups are hijacking the status of CSOs primarily for profit-seeking and unlike radical-extremist elements of "uncivil" society largely lack ideological base.

Unlike such informal institutions as kinship networks and informal mutual-assistance networks, "uncivil" society does little to positively affect the development of independent civil society in Georgia. To start with, subversive activities of "uncivil" groups presenting themselves as CSOs tarnish the image of civil society both for the state and for the public. With regard to the state-society relations, state actors, particularly in the context of the developing world, are rarely willing to distinguish among various types of CSOs in order to draw clear-cut parallels between civil and "uncivil" organisations. As long as a group poses as part of civil society, especially as concerns registered CSOs, the state applies a one-sizefits-all strategy in dealing with civil society. Talking about radical religious CSOs in Georgia, a representative of Georgian civil society observed that:

For instance, in Georgia we have these religion-tradition based communities which now create CSOs. They came out of the informal world and entered the formal world. This is a challenge because they are self-organized and you cannot prohibit ... [registration] or create some artificial barriers. At the same time, the government might consider creating these kinds of barriers and justifying the erecting of these barriers based on these examples, saying look what disastrous organizations are coming out and now we have to scrutinize the mechanisms of legalizing the NGOs. ${ }^{13}$

This example shows that having had negative experience with radical and extremist groups, masked under the term of civil society, the state might potentially employ additional deterrents for the establishment and registration of CSOs in its future practice with civil society.

The empirical objective of this article is not only to map the characteristics of "uncivil" society in Georgia, but also to examine its impact, or the lack thereof, on formal civil society. To that end, the following section offers an analysis of the uneasy relationship between civil and "uncivil" societies as well as of informal relations within formal civil society.

\section{Informal Sphere on Formal Civil Society}

Our empirical observation is the "uncivil" society draws heavily on widespread informal networks flourishing in Georgia, as well as in many other post-Soviet states. Widespread 
informality in the society provides fertile ground for the development and proliferation of "uncivil" groups. According to Lutsevych (2013), the Soviet Union left behind systemic corruption, informal networks and disengaged citizens who had no will to participate in public initiatives. Citizens are reluctant to engage in public initiatives and collective action. They view private connections and links to kinship networks as more useful for achieving their goals (Lutsevych 2013).

After the Rose Revolution, a number of institutional reforms implemented by Mikheil Saakashvili's government contributed to achieving a certain degree of decentralisation and the modernisation of formal institutions of the country, undermining the importance of informality (Aliyev 2015). After these reforms, the overall importance of informal practices decreased when dealing with the state bureaucracy, the education system, healthcare, law enforcement and some other areas. However, the reliance on informal practices has not completely disappeared and was continued to be used as coping mechanisms and social safety nets. As recorded by the EBRD survey in 2011, over 60 percent of the population in post-Rose Revolution Georgia relied on private social safety nets. Similarly, the Caucasus Barometer 2011 survey on volunteerism and civic participation showed that in the case of emergency, 95 percent of respondents would address their families rather than NGOs, state agencies or local governments. Nearly one third of respondents relied on connections when looking for jobs and about 10 percent used personal informal practices to access services related to healthcare and education (Aliyev 2014).

In Georgia, in-group social networks are strong within which people demonstrate extensive solidarity, but Georgians are rarely willing to formalise and institutionalise these collaborations. Thus, Georgia exhibits high degrees of bonding social capital and of trust and collaboration within tightly-knit groups. However, bridging the social capital that is needed to facilitate a more systematic cooperation between people representing different groups is still low. The prevalence of in-group social networks explains the low levels of membership in formalised associations. Instead of collaborative associations, Georgians prioritise close networks of family which leads to the lack of motivation to institutionalise informal practices and relations into formal institutions and associations (Caucasus Research Resource Centers 2011).

The survey on civic engagement in Georgia conducted by G-PAC in 2011 showed that most Georgians think that family comes first to help them in times of trouble. Hough (2011) thinks that the unquestioned norms of altruism within the family create some kind of informal insurance which can substitute for engagement with NGOs. Based on the answers of the majority of respondents that they would rely on their family in a time of crisis and only a small minority considering addressing an NGO for aid, she makes an argument that strong family and informal bonds in Georgia prevent engagement with the formal NGO sector. Responding to the question of why they are not interested in joining a civil society 
organisation, 37 percent of respondents said that they preferred to take care of their own family affairs.

On the one hand, scholars working on informality do not usually identify only the negative side of informal practices. Rather, informal networks provide post-Soviet citizens with different public goods such as assistance with unemployment, communal services and access to healthcare. In other words, informal networks also function as social safety nets assisting the population in times of financial difficulties and emergencies. On the other hand, public goods provided by informal institutions are usually distributed unequally. Whether or not one gets public goods depends on their kinship ties, ethnicity, social standing or position in a society (Aliyev 2014).

As with Georgian society in general, civil society activists also function as a certain in-group of individuals who are well connected to each other but are quite distanced from other groups of society. According to Lutsevych (2013), evidence suggests that in Georgia, as well as in Moldova and Ukraine, a rather elitist civil society sector has emerged. CSO leaders perceive citizens as their "target audience" or as beneficiaries of their services. Only 27 percent of surveyed by her described their organisations as an association of citizens. She thinks that activists of CSOs in these countries are much more efficient in networking with Western embassies and different state agencies than engaging with citizens. Nodia (2005) also characterises Georgian civil society as elitist, where mainly relatively young and welleducated city citizens are involved. The majority of developed organisations are located in the capital, and civil activity remains less developed outside of Tbilisi.

It is a widespread practice among Georgian NGOs to use informal networks and rely on patron-client relations when dealing with donors to secure funding for their activities. Personal connections, contacts or kinship ties are broadly used within the CSO sector of the country. Relying on private networks when dealing with state officials, collaborating with other CSOs, obtaining funding from donors and receiving donations from philanthropists is seen by CSO activists as a necessary tool for the normal functioning of their organisations. Over 80 percent of CSOs representatives interviewed in Georgia said that their organisations rely on informal networking when dealing with government officials. Despite the fact that anti-corruption reforms implemented in Georgia after 2003 have weakened the culture of bribery in formal institutions, the use of informal networks in the daily activities of NGOs remained widespread (Aliyev 2015). The use of informal networks is seen by CSO activists as a survival strategy in a competitive environment, assisting CSOs to function properly despite a lack of funding and human resources.

Even though the presence of informal networks is sometimes perceived as a positive phenomenon in transitional societies due to their ability to serve as coping mechanisms and provide their members with the public goods that the state or NGOs are not able to provide, 
informal networks play a negative role in terms of preventing the 'bridging' or transferring of social capital from the private into the public spheres and giving the shape of formal institutions to informal practices and relations. There is an overall consensus among scholars that the presence of strong in-group networks does not reflect positively on the development of a civil society.

Interviews conducted by the authors with experts, policy-makers and civil society activists in Georgia in July-September 2013 demonstrated that the existence of strong kinship ties is seen by some interviewees as contributing to the development of formal institutions since, due to well-developed 'bonding' social capital, the chances of people reaching those outside their kinship groups for the sake of the realisation of common interests and objectives increases. The heavy reliance on kinship networks, however, was identified by the majority of respondents as an obstacle for volunteerism and active participation in formal civil society organisations. As found by other studies, over 80 percent of informants think that strong kinship networks negatively affect volunteerism and the membership of CSOs (Aliyev 2014).

The importance of informal networks for the population and for the everyday activities of CSOs negatively reflects on the participation and membership of these organisations. Due to a high popular reliance on informal networks, people have less motivation to engage in the activities of formal civil society organisations. Membership of informal networks is viewed as more beneficial than that of formal civil society organisations. Even though informal mutual-assistance networks might have some beneficial impact on CSOs in the context of post-Soviet states, since it provides them with an opportunity to survive in a highly competitive environment, still its negative impact is more substantial. The prevalence of the informal sphere constitutes an obstacle for the emergence of open formal civil society organisations which are based on an association of citizens. Furthermore, the existence of strong informal networks makes it problematic to transfer a strong 'bonding' capital into 'bridging' by linking different in-groups of people to each other for achieving common goals.

\section{Impact of "Uncivil Society" on Formal Civil Society}

Low civil participation in the activities of formal civil society in combination with a high level of reliance on informal practices leads to the formation of "uncivil" society elements, which have a detrimental effect on formal CSOs. Although the prevalence of informal practices and networks creates a fertile soil for the emergence of the "uncivil" elements of CSOs, we are not arguing that the reliance on informal practices and networks makes CSOs "uncivil." There are informal movements and initiatives led by activists that are not "uncivil." In most cases, they do not have officially registered organisations or offices and operate through social media and networking to organise future events, protests and spread and sign petitions. The primary examples of this are green movements and environmentalist groups 
such as 'Guerilla Gardening,' 'Green Fist' and 'Tbilisi Hamqar,' uniting volunteer activists around a certain cause: the preservation of cultural heritage and the environment. Environmental activists have been regularly organising protest movements to criticise the 'Panorama Tbilisi' project, a multi-functional complex in the old part of the city which, according to protest participants, threatens to destroy Old Tbilisi's authenticity. ${ }^{14}$ As shown by this example, the reliance on informal practices is not enough for an organisation to be understood as "uncivil." In the case of "uncivil" CSOs, a combination of several factors is present: a heavy reliance on informal networking in parallel with propagating illiberal values.

Civil society organisations and radical extremist groups of "uncivil society" pursue different goals and use different means for achieving their aims. In 2013, the Georgian CSOs managed to initiate discussions on attempts to discriminate followers of non-major religions and, as a result, religious tolerance became a widely discussed topic in the public. CSO representatives were the first to draw attention to the issue of the protection of minority rights (Lortkipanidze, Pataraia 2014). In 2014, they actively rallied against manifestations of discrimination, hate speech and hate crimes. CSOs were at the centre of media attention regarding national discussions about surveillance policies and the alarming increase of gender-based violence (USAID 2014).

In contrast, radical groups presenting themselves as part of civil society have illiberal extremist agendas and aggressive means for the implementation of their goals. Nodia (2005) thinks that radical Orthodox organisations are examples of illiberal "uncivil" society in Georgia. Organisations like the 'Orthodox Parents Union' and the 'Union of Orthodox Parishes' propagate anti-liberal, nationalistic and radical religious values (Freedom House 2010). They claim that their main aim is to protect Eastern Orthodox values from the negative influence of Western liberalism. Some radical groups have been involved in violent attacks against religious minorities, civil society, the media and the political opposition (Freedom House 2008).

In May 2011, members of the newly-created 'People's Orthodox Christian Movement' attacked a peaceful demonstration against intolerance. Several days later, representatives of the same organisation assaulted journalists of one of the Georgian TV channels where the incident was being discussed (Freedom House 2011). Extremist religious organisations were active participants of one of the largest demonstrations held in Georgia in 2011 to protest against the law on religious minorities' legal status (Civil Georgia 2011) that would enable religious groups to register as legal entities, solving the problem of the undefined status of religious minorities in Georgia (Freedom House 2012). In May 2014, radical religious organisations were protesting against an anti-discrimination law that included sexual orientation and gender identity among the banned grounds for bias (Freedom House 2015). 
"Uncivil" organisations negatively impact formal CSOs by representing themselves as similar to formal civil society organisations, associating them to their illiberal agenda. Georgian media refers to all CSOs as NGOs or human rights defenders regardless of their institutional record and activities. The views of groups with extremist political and religious positions are often reported as the views of CSOs or human rights defenders, further blurring the concept of CSOs among the public (USAID 2014). This has a negative effect on how CSOs are perceived by the public and the government of the country. One illustrative example was offered by an NGO official: ${ }^{15}$

Some leaders of radical [civil] groups insist that they are true members of civil society because they represent national values and traditions, unlike proWestern NGOs which, they say, are just "puppets" of foreign regimes that do not care about the people. There are frequent efforts made by religious and conservative CSOs to badmouth other NGOs, particularly those which criticize their activities.

In the context of the low public awareness about civil society organisations, ambiguous media reporting about the activities of civil and "uncivil" society makes it even more difficult for the population to distinguish one from another and strengthens the negative image of civil society organisations. Thus, if in the case of informal networks and practices it is possible to mark some positive effects on the formal civil association together with many negative ones, in terms of the darker side of the informal sphere, "uncivil" society and its impact on the CSO development process in Georgia is largely negative.

\section{Conclusion}

This article has sought to examine the role of informal structures within the Georgian civil sector with an empirical focus on the "uncivil" elements within the NGO sector such as radical or controversial groups engaged in activities contradicting the key principles of civil society. Bearing in mind the lack of clarity among the population as to what civil society is, the borderline between civil and "uncivil" functions of CSOs becomes indistinguishable. As a consequence, informal relations within the NGO sector seem to dominate formal frameworks. This merger between civil and "uncivil" societies and the de-formalisation of the civil sector is a phenomenon not endemic to post-Soviet Georgia. Rather, similar processes might be expected to exist in many other post-Communist countries. The case study of Georgian civil society - described in this study - provides an initial framework for the further study of informal relations within post-communist civil societies. These findings lend preliminary support to the assumption that "uncivil" society manifests itself within the post-Soviet civil sectors. Although we do not exclude the possibility of the endogeneity of our argument and that informal CSOs exist because formal CSOs fail to address the public's needs and because there is Soviet-era tradition of informality in society, it is evident that 
informal and "uncivil" structures also have a negative effect on the workings of formal civil society.

This study offers two recommendations for future policy and research. Firstly, bearing in mind the existence of "uncivil" CSOs in the South Caucasus, it is imperative for foreign donors to take into account not only the formal objectives and mission of partner NGOs, but also their methods of operation and their reliance on informal channels in their day-to-day work. The lack of clear-cut distinctions between civil and "uncivil" organisations may cause confusion on the part of foreign donors, particularly those funding agencies that are either new to the region or are operating from outside of the former Soviet Union. Secondly, as informal relations remain firmly rooted across the former Soviet Union, it is crucial to distinguish between the negative sides of informality - such as the transformation of civil society into the "uncivil" one - and its positive effects. These recommendations could improve our understanding of civil society in the South Caucasus, offering both academics and practitioners better understanding of how CSOs function.

Acknowledgements: This article has received funding from the European Union's Seventh Framework Programme for research, technological development and demonstration under the European project CASCADE GA No. 613354.

We would like to thank Nino Kemoklidze, Laurence Broers, and two anonymous reviewers for their valuable contribution to this study.

\section{References}

Ademi, Tanja H. and Hadjievska, Milka I. "Enabling Environment for Civil Society Development in the Black Sea Region: Towards a Regional Strategy for Cooperation." Balkan Civil Society Development Network, Mapping Study August 2015.

Aliyev, Huseyn. "Civil Society in the South Caucasus: Kinship Networks as Obstacles to Civil Participation." Southeast European and Black Sea Studies 14.2 (2014): 263-282.

Aliyev, Huseyn. "The Effects of the Saakashvili Era Reforms on Informal Practices in the Republic of Georgia." Studies of Transition States and Societies 6.1 (2014): 19-33.

Aliyev, Huseyn. "Examining the Use of Informal Networks by NGOs in Azerbaijan and Georgia." Journal of Civil Society 11.3 (2015a): 317-332.

Aliyev, Huseyn. Post-Communist Civil Society and the Soviet Legacy: Challenges of Democratisation and Reform in the Caucasus. Palgrave Macmillan, 2015b.

Amado, Gelles, and Haroldo Vinagre Brasil. "Organizational Behaviors and Cultural Context: The Brazilian 'Jeitinho.'" International Studies of Management and Organization (1991): 38-61. 
Ambrosio, Thomas. "Constructing a Framework of Authoritarian Diffusion: Concepts, Dynamics and Future Research." International Studies Perspectives, 11.4 (2010): 375-392.

Babajanian, Babken V. "Social Capital and Community Participation in Post-Soviet Armenia: Implications for Policy and Practice." Europe-Asia Studies 60.8 (2008): 1299-1319.

Boeke, Julius Herman. Economics and Economic Policy of Dual Societies as Exemplified by Indonesia. AMS Press, 1953.

Böröcz, József. "Informality Rules." East European Politics and Societies 14.2 (2000): 348380.

Bromley, Ray and Chris Gerry, eds. Casual Work and Poverty in Third World Cities. Chichester: Wiley, 1979.

Castells, Manuel and Alejandro Portes. The World Underneath: The Dynamics and Effects of the Informal Economy. Publisher not identified, 1987.

Civil Georgia. "Thousands Protest Law on Religious Minorities Legal Status." 10 July 2011. http://www.civil.ge/eng/article.php?id=23728

Cohen, Jean, and Andrew Arato. "Political Theory and Civil Society." (1992).

Coleman, James S. "Social Capital in the Creation of Human Capital." American Journal of Sociology (1988): S95-S120.

Collins, Kathleen. Clan Politics and Regime Transition in Central Asia. Cambridge: Cambridge University Press, 2006.

Collins, Kathleen. "Ideas, Networks and Islamist Movements: Evidence from Central Asia and the Caucasus." World Politics 60.01 (2007): 64-96.

Cooley, Alexander and James Ron. "The NGO Scramble: Organizational Insecurity and the Political Economy of Transnational Action." International Security 27.1 (2002): 5-39.

Cunningham, Robert B. and Yasin K. Sarayrah. Wasta: The Hidden Force in Middle Eastern Society. Praeger Publishers, 1993.

Curro, Costanza. "A critical assessment of informal practices as resistance: the case of birzha in Georgia." Caucasus Survey 5.1 (2017): 65-84.

Democracy and Freedom Watch. "In Georgia, NGOs are Looking for People's Trust." March 14, 2012. http://dfwatch.net/in-georgia-ngos-are-looking-for-peoples-trust-34213$\underline{6746}$

De Soto, Hernando. "The Other Path: The Informal Revolution." New York (1989).

De Sousa, Luís, Barry Hindess, and Peter Larmour, eds. Governments, NGOs and AntiCorruption: The New Integrity Warriors. Routledge, 2012.

De Tocqueville, Alexis, Jacob Peter Mayer and André Jardin. L'ancien régime et la révolution. Vol. 55. Paris: Gallimard, 1967.

Ehrenberg, John. Civil Society. NYU Press, 1999.

\begin{tabular}{|c|c|c|c|c|c|c|}
\hline Freedom & House. & Nations & in & Transit & Georgia, & 2008. \\
\hline \multicolumn{7}{|c|}{ https://freedomhouse.org/report/nations-transit/2008/georgia } \\
\hline om & House. & Nations & in & Transit & Georgia, & 2011. \\
\hline
\end{tabular}




\begin{tabular}{|c|c|c|c|c|c|c|}
\hline Freedom & House. & Nations & in & Transit & Georgia, & 2011 \\
\hline \multicolumn{7}{|c|}{ https://freedomhouse.org/report/nations-transit/2011/georgia } \\
\hline Freedom & House. & Nations & in & Transit & Georgia, & 2012 \\
\hline \multicolumn{7}{|c|}{ https://freedomhouse.org/report/nations-transit/2012/georgia } \\
\hline Freedom & House. & Nations & in & Transit & Georgia, & 20 \\
\hline
\end{tabular}

Gerxhani, Klarita. "The Informal Sector in Developed and Less Developed Countries: A Literature Survey." Public Choice 120.3 (2004): 267-300.

Gibson, James L. "Social Networks, Civil Society and the Prospects for Consolidating Russia's Democratic Transition." American Journal of Political Science (2001): 51-68.

Granovetter, Mark S. "The Strength of Weak Ties." American Journal of Sociology (1973): 1360-1380.

Green, Andrew T. and Richard D. Kohl. "Challenges of Evaluating Democracy Assistance: Perspectives from the Donor Side." Democratisation 14.1 (2007): 151-165.

Grødeland, Åse Berit and Aadne Aasland. "Informality and Informal Practices in East Central and South East Europe." CERC (Contemporary Europe Research Centre, University of Melbourne) Working Papers Series 3 (2007).

Grødeland Åse B. and Aasland Aadne. "Civil Society in Post-Communist Europe: Perceptions and Use of Contacts." Journal of Civil Society 7.2 (2011): 129-156.

Habibov, Nazim. "How and Why Determinants of Household Welfare Changed in Azerbaijan during the Transition: Lessons from National Surveys." Problems of Economic Transition 54.11 (2012): 3-52.

Hart, Keith. "Informal Income Opportunities and Urban Employment in Ghana." Journal of Modern African Studies 11.01 (1973): 61-89.

Helmke, Gretchen and Steven Levitsky. "Informal Institutions and Comparative Politics: A Research Agenda." Perspectives on Politics 2.04 (2004): 725-740.

Hooghe, Marc and Dietlind Stolle, eds. Generating Social Capital - Civil Society and Institutions in a Comparative Perspective. Houndsmill: Palgrave Macmillan, 2003.

Hough, Leslie. "Civic Engagement in Georgia: The Challenge of Formalizing the Informal." IREX, Scholar Research Brief. September 2011.

Howard, Marc Morjé. The Weakness of Civil Society in Post-Communist Europe. Cambridge University Press, 2003.

Howard, Marc Morjé. "The Weakness of Post-Communist Civil Society." Journal of Democracy. 13.1 (2002): 157-169.

Ishkanian, Armine. Democracy Building and Civil Society in Post-Soviet Armenia. Routledge, 2008.

Keane, John. "Civil Society: Old Images." New Visions (1998).

Khutsishvili, George. "Civil Society and the Rose Revolution in Georgia." Tbilisi: ICCN, 2008.

Kopecký, Petr and Cas Mudde. "Uncivil Society." Contentious Politics in Post-Communist Europe (2003). 
Kopecký, Petr. "Civil Society, Uncivil Society and Contentious Politics in Post-Communist Europe." Uncivil Society (2003): 1-18.

Ledeneva, Alena V. Russia's Economy of Favours: Blat, Networking and Informal Exchange. Vol. 102. Cambridge University Press, 1998.

Lewis, David. "Civil Society in African Contexts: Reflections on the Usefulness of a Concept." Development and Change 33.4 (2002): 569-586.

Lomnitz, Larissa Adler. "Informal Exchange Networks in Formal Systems: A Theoretical Model." American Anthropologist 90.1 (1988): 42-55.

Lortkipanidze, Shorena and Pataraia, Tamara. "Mapping Study of Civil Society Organisations' Engagement in Policy Dialogue in Georgia." Civil Society, Dialogue for Progress. Report October 2014.

Luong, Pauline Jones. Institutional Change and Political Continuity in Post-Soviet Central Asia: Power, Perceptions and Pacts. Cambridge University Press, 2002.

Lutsevych, Orysia. "How to Finish a Revolution: Civil Society and Democracy in Georgia, Moldova and Ukraine." Chatham House, Briefing Paper. January 2013. https://www.chathamhouse.org/sites/files/chathamhouse/public/Research/Russia \%20and\%20Eurasia/0113bp lutsevych.pdf

Mead, George Herbert. Mind, Self and Society: From the Standpoint of a Social Behaviorist. Vol. 1. University of Chicago Press, 2009.

Misztal, Barbara. Informality: Social Theory and Contemporary Practice. Routledge, 2002.

Morris, J. and A. Polese. "Introduction: Informality - Enduring Practices, Entwined Livelihoods." The Informal Post-Socialist Economy: Embedded Practices and Livelihoods. London and New York: Routledge (2014).

Muskhelishvili, Marina and Gia Jorjoliani. "Georgia's Ongoing Struggle for a Better Future Continued: Democracy Promotion through Civil Society Development." Democratization 16.4 (2009): 682-708.

Nodia, Ghia. "Civil Society Development in Georgia: Achievements and Challenges." Tbilisi, CIPDD (2005).

North, Douglass C. Institutions, Institutional Change and Economic Performance. Cambridge University Press, 1990.

O'Donnell, Guillermo A. "Delegative Democracy." Journal of Democracy 5.1 (1994): 55-69.

Paturyan, Yevgenya and Gevorgyan, Valentina. "Trust Towards NGOs and Volunteering in the South Caucasus: Civil Society Moving Away from Post-Communism?." Southeast European and Black Sea Studies 14.2, 239-262.

Polese, Abel. "'If I receive it, it is a gift; if I demand it, then it is a bribe:' On the Local Meaning of Economic Transactions in Post-Soviet Ukraine." Anthropology in Action 15.3 (2008): 47-60.

Putnam, Robert, Robert Leonardi and Raphaëlle Nanetti. "Making Democracy Work." Princeton University Press (1993).

Rekhviashvili, Lela. "Counterbalancing marketization informally: Georgia's new-institutionalist reform and its discontents." Journal of Contemporary Central and Eastern Europe 24.3 (2016): 255272. 
Rekhviashvili, Lela, and Abel Polese. "Liberalism and shadow interventionism in post-revolutionary Georgia (2003-2012)." Caucasus Survey 5.1 (2017): 27-50.

Rose, Richard. "Russia as an Hour-Glass Society: A Constitution without Citizens." E. Eur. Const. Rev. 4 (1995): 34.

Rothstein, Bo and Dietlind Stolle. "The State and Social Capital: An Institutional Theory of Generalized Trust." Comparative Politics 40. 4 (2008): 441-459.

Round, John, and Colin Williams. "Coping with the Social Costs of 'Transition:' Everyday Life in Post-Soviet Russia and Ukraine." European Urban and Regional Studies 17.2 (2010): 183-196.

Sayfutdinova, Leyla. "Post-Soviet small businesses in Azerbaijan: the legacies of the Soviet second economy." Caucasus Survey 5.1 (2017): 11-26.

Shelley, Louise, Erik R. Scott and Anthony Latta, eds. Organized Crime and Corruption in Georgia. Routledge, 2007.

Slade, Gavin. "Informality as illegality in Georgia's anti-mafia campaign." Caucasus Survey 5.1 (2017): 51-64.

Smith, Adrian. "Culture/Economy and Spaces of Economic Practice: Positioning Households in Post-Communism." Transactions of the Institute of British Geographers 27.2 (2002): 232-250.

Smith, Daniel Jordan. "Corruption, NGOs and Development in Nigeria." Third World Quarterly 31.2 (2010): 243-258.

Souleimanov, Emil and Huseyn Aliyev. The Individual Disengagement of Avengers, Nationalists, and Jihadists: Why Ex-Militants Choose to Abandon Violence in the North Caucasus. Palgrave Macmillan, 2014.

Svanidze, Tamar. Georgia Today. "Massive Protest Continues against Panorama Tbilisi Construction." February 29, 2016. http://georgiatoday.ge/news/3116/TbilisiResidents-Protest-Ivanishvili\%E2\%80\%99s-Panorama-Project-\%5BPhotos\%5D

Swietochowski, Tadeusz. "Azerbaijan: The Hidden Faces of Islam." World Policy Journal (2002): 69-76.

USAID, Sustainability Index for 2009. Washington DC: United States Agency for International Development, 2009.

USAID, The 2014 CSO Sustainability Index for Central and Eastern Europe and Eurasia.

Washington DC: United States Agency for International Development, 2014. https://www.usaid.gov/sites/default/files/documents/1863/EuropeEurasia FY2014 CSOSI Report.pdf\#page $=20$

WVS. "World Values Surveys and European Values Surveys, 1981-1984, 1990-1993 and 1995-1997." (2000).

Yang, Mayfair Mei-hui. Gifts, Favors and Banquets: The Art of Social Relationships in China. Cornell University Press, 1994.

\section{Notes}

\footnotetext{
${ }^{1}$ Affiliated Fellow at the Research Centre for East European Studies, University of Bremen.
} 
${ }^{2}$ Lord Kelvin Adam Smith (LKAS) Research Fellow, Central and Eastern European Studies, University of Glasgow.

${ }^{3}$ We borrow our definition of informal institutions from Helmke and Levitsky (2004: 727) who define informal institutions as "socially shared rules, usually unwritten, that are created, communicated, and enforced outside of officially sanctioned channels."

${ }^{4}$ According to Putnam et al. (1993), social capital "bonding" is a process of inter-personal networking occurring within closed networks. Social capital bridging enables networks to communicate and exchange information with other networks. The networks' failure to "bridge" leads to limited interaction between various parts of society. Because the lack of "bridging" inhibits the transfer of social capital from private into public sphere, it is detrimental for civil society.

${ }^{5}$ It is noteworthy that formal civil society in the South Caucasus, as well as in other nonWestern contexts (Lewis 2002), is not limited to Non-Governmental Organisations (NGOs), but also consists of a myriad of informal social movements and grassroots organisations. These groups do not always function as NGOs and, therefore, are part of a broader concept - social capital (Putnam et al. 1993). In this study, social capital - which is understood as a sum of social relations and interactions within a society (Coleman 1998) - is seen through the lenses of one of its constituents: informal networks. The next level of distinction is concerned with disaggregating those civil society organisations (CSOs), which work as mainstream civil society, and those, which engage in activities that may fall beyond the range of tasks performed by CSOs in most developed welfare states (Putnam 1993).

${ }^{6}$ We approach the topic of civil society with a focus on registered civil society organisations (CSO) and informal and unregistered "civic" groups and movements. We apply the term CSOs - a broader concept than non-governmental organisations (NGOs) - to describe all legally registered civil associations (Keane 1998).

${ }^{7}$ Firstly, initial empirical support for the arguments raised in this article was found from a series of elite interviews conducted by the authors in Georgia. A total of 24 qualitative open-ended interviews were conducted with CSO officials, experts and representatives of international organisations based in Georgia in 2013. A non-random "snowball" method was used to recruit informants. Interview questions and topics were aimed at learning about the functioning of Georgian civil society and about the role of informal relations in the work of NGOs. Secondly, a wide range of academic studies, mass media reports and reports by international organisations was used to support interview findings and to place them within the relevant context.

${ }^{8}$ Caucasus Research Resource Centres (CRRC), accessible at: http://crrc.ge.

${ }^{9}$ Authors' interview with a civil society activist, Baku, September 27, 2013.

${ }^{10}$ Authors' interview with a member of an advocacy CSO, Tbilisi, August 23, 2013.

${ }^{11}$ Authors' interviews with a number of civil society activists in Tbilisi, August-September, 2013.

${ }^{12}$ Authors' interview with a scholar and NGO official at Ilia State University, Tbilisi, September 10, 2013.

${ }^{13}$ Authors' interview with a scholar and NGO official at Ilia State University, Tbilisi, September 10, 2013.

14 Tamar Svanidze, Georgia Today, "Massive Protest Continues Against Panorama Tbilisi Construction", February 29, 2016, http://georgiatoday.ge/news/3116/Tbilisi-Residents-ProtestIvanishvili\%E2\%80\%99s-Panorama-Project-\%5BPhotos\%5D 
${ }^{15}$ Authors' interview with the head of an independent NGO, Tbilisi, September 08, 2013. 